\title{
Metabolic Response to Oral Glucose in Healthy South African White, Indian, and African Subjects
}

\author{
A. H. RUBENSTEIN,* M.B., F.C.P.(S.A.), M.R.C.P. ; H. C. SEFTEL, † M.B., B.SC., DIP.MED. ; K. MILLER, $\ddagger$ CHEM.ENG. \\ I. BERSOHN, $\S$ M.B., B.SC., F.C.PATH ; A. D. WRIGHT, M.B., M.R.C.P.
}

Brit. med. F., 1969, 1, 748-751

Cummary: The response of serum insulin, growth $\checkmark$ hormone, plasma free fatty acids, triglycerides, and blood glucose to an oral glucose load was investigated in healthy White, African, and Indian subjects. Serum cholesterol, uric acid, platelet adhesiveness, and urine insulin clearance were also measured. Each racial group responded differently. Most striking were the differences between Africans and Whites; despite similar mean blood glucose values at all times during the test, the Africans had lower serum insulin levels, a lower urine insulin clearance, a much greater rise of growth hormone, a more definite and prolonged suppression of free fatty acid release, lower serum cholesterol and uric acid levels, and a trend towards lower plasma triglyceride values.

The Indians tended to resemble Whites rather than Africans with respect to their insulin, growth hormone, cholesterol, and triglyceride levels. Their glucose tolerance was decreased compared with that of the other two groups, but suppression of their free fatty acids was enhanced. Platelet adhesiveness was similar in all three groups.

The reasons for these differences are unknown, but must be related to genetic and environmental differences among the three races.

\section{Introduction}

It is well known that the various race groups in South Africa differ markedly in regard to the prevalence of ischaemic heart disease (Seftel et al., 1963b, 1965; Walker, 1963a, 1966b) and diabetes mellitus (Campbell, 1963 ; Richardson et al., 1965 ; Seftel et al., 1963a ; Walker et al., 1964). The former condition is very common in both Whites and Indians but is rare among Africans (Walker, 1963b), even in those who have been urbanized for many years. The prevalence of diabetes among Indians is greater than that in most White populations (Campbell, 1963), while among Africans the disease, though on the increase, is still relatively uncommon (Richardson et al., 1965 ; Seftel et al., 1963a). The reasons for these interracial differences remain obscure despite a great deal of clinical, epidemiological, and biochemical study in both normal and diseased subjects (Walker, 1966a, 1967). In this paper we have sought to throw light on the problem by investigating the response of serum insulin, growth hormone, plasma free fatty acids, triglycerides, and blood glucose to an oral glucose load in carefully matched healthy White, African, and Indian sub-

* Formerly Medical Registrar, Department of Medicine, University of the Witwatersrand and Johannesburg General Hospital. Present position: Assistant Processor of Medicine, University of Chicago, Chicago, Illinois, U.S.A.

† Physician, Department of Medicine, University of the Witwatcrsrand and Johannesburg Hospital.

t Research Assistant, Department of Pharmacology, University of the Witwatersrand, Johannesburg.

Superintendent, Clinical Pathology, and Head, Cardiovascular Research Unit, South African Institute for Medical Research, Johannesburg.

|| M.R.C. Research Fellow, Department of Medicine, Postgraduate Medical School and Hammersmith Hospital, London W.12. jects. Serum cholesterol, uric acid, platelet adhesiveness, and urine insulin clearance were also measured.

\section{Subjects and Methods}

Seven African, seven Indian, and eight White healthy male subjects were studied. None of them had a family history of diabetes mellitus. All the Africans were manual labourers, while the Indians and Whites were clerks or traders. Dietary histories of adequate nutrition and carbohydrate intake were ascertained. The subjects fasted from $10 \mathrm{p.m}$. on the evening before the test, which began at 8 a.m. the following morning. They rested for at least half an hour in a quiet room before the study was begun. After emptying the bladder a fasting specimen of venous blood was taken and $1 \mathrm{~g}$. of glucose per kilogram body weight was given by mouth as a $15 \%$ solution in water ; further venous blood samples were taken at 30,60,120,180, and 240 minutes. A four-hour sample of urine was collected.

Glucose was measured on whole blood by the ferricyanide reduction method on the Technicon AutoAnalyzer (Hoffman, 1937). Insulin was assayed in serum by the double antibody precipitation method of Morgan and Lazarow (1963) modified by Welborn and Fraser (1966), a human insulin standard being used; growth hormone in serum was measured by a similar technique (Hartog et al., 1964). After adjustment of $p \mathrm{H}$ and centrifugation, urine insulin was assayed as previously described (Rubenstein et al., 1967a). The serum and insulin results were expressed logarithmically (Chlouverakis et al., 1967 ; Welborn et al., 1966b). An " insulin clearance" was calculated from the mean serum level and the four-hour urine insulin excretion (Rubenstein et al., 1967b). Creatinine was determined on urine and serum samples according to Wootton (1964).

Blood was prepared for free fatty acid and triglyceride determinations by collection in heparinized tubes, chilled to $4^{\circ} \mathrm{C}$., and separated immediately. The plasma free fatty acids were extracted within an hour and titrated potentiometrically with $0.02 \mathrm{~N}$ alcoholic potassium hydroxide (Trout et al., 1960 ; Schnatz, 1964). The result was read from a curve, palmitic acid being used as a standard. Plasma lipids were extracted according to Folch et al. (1957) and triglycerides determined by the method of Ross (1967) and the colorimetric principle of Van Handel and Zilversmit (1957). Serum cholesterol was measured by the method of Pearson et al. (1953) and uric acid according to Eichhorn et al. (1961) on the fasting sample. Platelet adhesiveness was determined on whole blood in the fasting state (Morris and Miller, 1966).

\section{Results}

Clinical Features.-The composition of the groups with regard to age, height, weight, and percentage of ideal body weight (Society of Actuaries, 1959) is shown in Table I. Although the mean absolute weight of the subjects in the three groups differed, this was mainly a consequence of the greater height of the Whites. When expressed as a percentage of ideal body weight, there was no significant difference between the 
three race groups. All subjects had normal blood pressures and their blood urea levels were below $40 \mathrm{mg} . / 100 \mathrm{ml}$. Protein was not detected in their urine specimens.

TABle I.-Age, Weight, Percentage Ideal Body Weight, and Height in African, Indian, and White Subjects (Mean \pm S.D.)

\begin{tabular}{ll|c|c|c|c}
\hline \multicolumn{1}{c|}{ Subjects } & Age in Years & $\begin{array}{c}\text { Weight } \\
\text { (kg.) }\end{array}$ & $\begin{array}{c}\text { Ideal Body } \\
\text { Weight } \\
(\%)\end{array}$ & $\begin{array}{c}\text { Height } \\
(\mathrm{cm} .)\end{array}$ \\
\hline \begin{tabular}{ll|c|c} 
African \\
Indian
\end{tabular} & $\cdots$ & $30 \pm 6$ & $61 \pm 6$ & $89 \pm 10$ & $168 \pm 6$ \\
White & $\cdots$ & $27 \pm 7$ & $63 \pm 6$ & $96 \pm 12$ & $165 \pm 4$ \\
& & $74 \pm 9$ & $100 \pm 12$ & $178 \pm 6$ \\
\hline
\end{tabular}

Blood Glucose.-All subjects had blood glucose levels below $120 \mathrm{mg} . / 100 \mathrm{ml}$. at 120 minutes and $100 \mathrm{mg} . / 100 \mathrm{ml}$. at 180 minutes (Table II). The mean fasting value of $86 \mathrm{mg} . / 100 \mathrm{ml}$. in the Indians was higher than that of the other two groups and was significantly different from the African level $(P<0.05)$. This trend was accentuated at 30 minutes after glucose loading, when both the African and White levels were markedly lower than that of the Indians ( $P<0.001$ and $P<0.01$, respectively). The groups did not differ significantly at 60 minutes, but at 120 and 180 minutes the Indians were again higher than the Whites $(P<0.05)$ and at 240 minutes higher than the Africans $(\mathrm{P}<0.02)$. The mean glucose curve of the Africans did not differ significantly from that of the Whites at any time during the test.

Serum Insulin.-Fasting insulin values were similar in the three groups. In response to glucose Indian and White levels were similar, but African values were lower than those of Whites (Table II). The mean insulin levels at 30 minutes were Whites 115 and Africans $61 \mu \mathrm{U} . / \mathrm{ml} .(\mathrm{P}<0.02)$. The mean area under the insulin curve, expressed as $\mu \mathrm{U}$.-minutes, was 11,100 in Whites and 7,980 in Africans $(P<0.02)$.

Serum Growth Hormone.-The mean fasting level of $4.2 \mathrm{~m} \mu \mathrm{g} . / \mathrm{ml}$. in Africans was higher than the White and Indian values of 2.3 and $2.7 \mathrm{~m} \mu \mathrm{g}$. $/ \mathrm{ml}$. respectively, but the differences were not significant. All three groups showed the expected rise of growth hormone during the latter part of the test (Fig. 1), but the increase was most marked among the Africans, five of whom reached values in excess of $50 \mathrm{~m} \mu \mathrm{g} . / \mathrm{ml}$. Of the 15 Whites and Indians, only three attained such high levels (Table III).

Plasma Free Fatty Acids.-The mean fasting levels of free fatty acids (Table II) was 466,378 , and $350 \mu \mathrm{Eq} / \mathrm{l}$. for Africans, Indians, and Whites respectively $(\mathrm{P}<0.02$ between Whites and Africans). In order to compare the groups the values during the next four hours were expressed as a percentage of the fasting level (Fig. 2). Africans and Whites showed a lesser fall than Indians at 30 minutes, the difference between Africans and Indians being significant $(P<0.01)$. Towards the latter end of the curve the free fatty acids of Africans and Indians remained suppressed for longer than those of the Whites and at 180 minutes the levels of the former groups were lower than the level of the Whites $(P<0.01$ and $P<0.05$, respectively).
Plasma Triglycerides.-These were estimated during the four hours of the glucose tolerance test in samples of five subjects chosen at random from each group. As there was a wide range of triglyceride values, the mean levels did not differ significantly

TABLE III.-Individual Serum Growth Hormone Levels Four Hours After Glucose in African, Indian, and White Subjects $(m \mu \mathrm{g} . / \mathrm{ml}$.)

\begin{tabular}{c|c|c|c}
\hline Subjects & African & Indian & White \\
\hline 1 & $>50$ & 5.6 & $5 \cdot 7$ \\
2 & $>50$ & 3.6 & 6.3 \\
3 & $>50$ & 3.5 & 12.0 \\
4 & $>50$ & 11.0 & 2.7 \\
5 & 16 & 250 & 42.0 \\
6 & $>50$ & $>50$ & 4.6 \\
7 & & & $>50$ \\
8 & & 1.8 \\
\hline
\end{tabular}

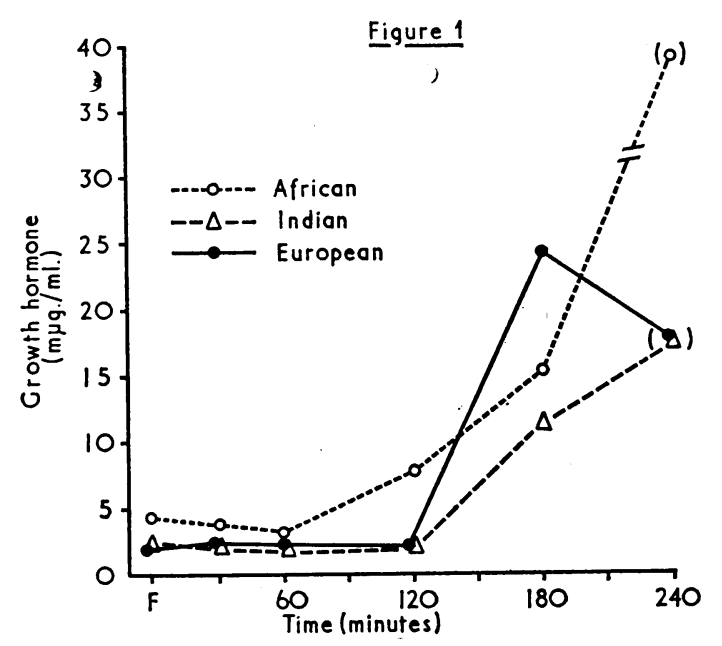

FIG. 1.- Serum growth hormone response to oral glucose in the three race groups (men \pm standard error). The values plotted at 240 minutes are approximations, as levels in excess of $50 \mathrm{~m} \mu \mathrm{g} . / \mathrm{ml}$. were not precisely determined.

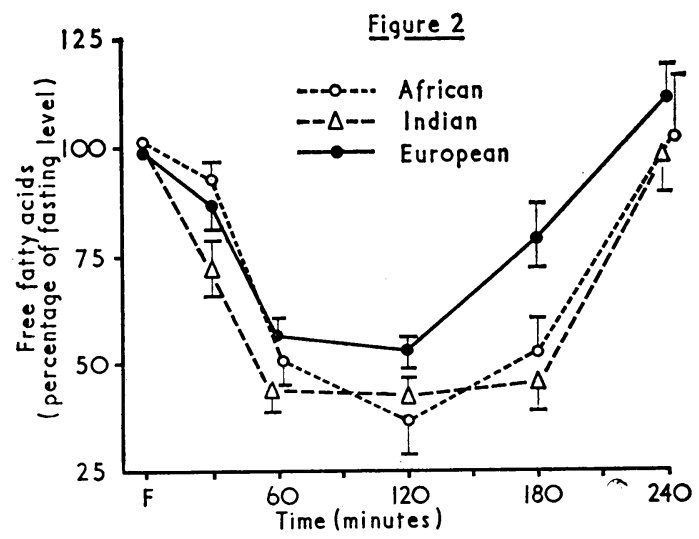

FIG. 2.-Plasma free fatty acid response to oral glucose in the three race groups (mean \pm standard error). The values are plotted as percentages of the fasting level.

TABle II.-Blood Glucose, Serum Insulin, Plasma Free Fatty Acid, and Triglyceride Levels During Oral Glucose Tolerance Test (Mean \pm S.D.)

\begin{tabular}{|c|c|c|c|c|c|c|c|c|}
\hline & & & \multicolumn{6}{|c|}{ Minutes after Glucose } \\
\hline & & & 0 & 30 & 60 & 120 & 180 & 240 \\
\hline $\begin{array}{l}\text { Blood } \\
\text { glucose } \\
\text { (mg./100 ml.) } \\
\text { Serum } \\
\text { insulin* } \\
\text { ( } \mu \mathrm{U} . / \mathrm{ml} .) \\
\text { Plasma free } \\
\text { fatty acid } \\
\text { ( } \mu \text { Eq/1.) } \\
\text { Plasma } \\
\text { triglyceride } \\
\text { (mg. } / 100 \mathrm{ml} .)\end{array}$ & $\begin{array}{l}\text { African } \\
\text { Indian } \\
\text { | White } \\
\text { African } \\
\text { Indian } \\
\text { I White } \\
\text { African } \\
\text { Indian } \\
\text { White } \\
\text { African } \\
\text { Indian } \\
\text { I White }\end{array}$ & $\begin{array}{l}\because \\
\because \\
\because \\
\because \\
\because \\
\because \\
\because \\
\because\end{array}$ & $\begin{array}{c}73 \pm 9 \\
86 \pm 12 \\
74 \pm 10 \\
0 \cdot 8334 \pm 0.2016(6) \\
1 \cdot 0155 \pm 0.1994(10) \\
0 \cdot 7638 \pm 0 \cdot 2487(6) \\
466 \pm 81 \\
378 \pm 80 \\
350 \pm 68 \\
74 \pm 14 \\
104 \pm 27 \\
105 \pm 55\end{array}$ & $\begin{array}{c}93 \pm 17 \\
139 \pm 23 \\
103 \pm 21 \\
1 \cdot 7828 \pm 0 \cdot 2874(61) \\
1 \cdot 9733 \pm 0 \cdot 3262(94) \\
2 \cdot 0582 \pm 0 \cdot 1785(115) \\
430 \pm 86 \\
255 \pm 72 \\
301 \pm 81 \\
70 \pm 10 \\
89 \pm 30 \\
90 \pm 42\end{array}$ & $\begin{array}{c}94 \pm 24 \\
110 \pm 34 \\
92 \pm 31 \\
1 \cdot 6728 \pm 0 \cdot 3294(47) \\
1 \cdot 8477 \pm 0.2019(70) \\
1 \cdot 8751 \pm 0 \cdot 2172(75) \\
235 \pm 73 \\
168 \pm 52 \\
198 \pm 74 \\
71 \pm 25 \\
78 \pm 32 \\
80 \pm 32\end{array}$ & $\begin{array}{c}83 \pm 20 \\
92 \pm 8 \\
72 \pm 24 \\
1 \cdot 4679 \pm 0 \cdot 2598(29) \\
1 \cdot 6020 \pm 0 \cdot 3590(40) \\
1 \cdot 5375 \pm 0 \cdot 3930(35) \\
173 \pm 51 \\
160 \pm 44 \\
181 \pm 69 \\
70 \pm 11 \\
74 \pm 22 \\
78 \pm 24\end{array}$ & $\begin{array}{c}76 \pm 16 \\
80 \pm 10 \\
64 \pm 10 \\
1 \cdot 1579 \pm 0 \cdot 2140(14) \\
1 \cdot 0683 \pm 0 \cdot 3330(12) \\
1 \cdot 0144 \pm 0 \cdot 2676(10) \\
243 \pm 96 \\
172 \pm 54 \\
278 \pm 48 \\
60 \pm 16 \\
79 \pm 19 \\
88 \pm 34\end{array}$ & $\begin{array}{c}63 \pm 13 \\
79 \pm 9 \\
71 \pm 12 \\
0 \cdot 8715 \pm 0 \cdot 2862(7) \\
0.9040 \pm 0 \cdot 2326(8) \\
0 \cdot 8451 \pm 0 \cdot 1852(7) \\
477 \pm 131 \\
370 \pm 113 \\
388 \pm 62 \\
66 \pm 22 \\
93 \pm 44 \\
102 \pm 59\end{array}$ \\
\hline
\end{tabular}

* Log 10 values. The mean absolute levels are indicated in parentheses. 
in the three races. However, two White and two Indian subjects had fasting levels above $100 \mathrm{mg} . / 100 \mathrm{ml}$., while the range in Africans was $56-90 \mathrm{mg} . / 100 \mathrm{ml}$. The triglycerides of all three groups fell after the administration of glucose, the drop being more pronounced in those subjects with higher fasting values (Table II).

Serum Cholesterol.-The fasting cholesterol level of Africans was significantly lower than that of Indians and Whites $(\mathrm{P}<0.05$ and $\mathrm{P}<0.02$, respectively). The mean values were 153,186 , and $197 \mathrm{mg} . / 100 \mathrm{ml}$. in the three groups (Table IV).

Serum Uric Acid.-The mean values of Africans, Indians, and Whites were $4.5,5.0$, and $5.8 \mathrm{mg} . / 100 \mathrm{ml}$. (Table IV), the level in Whites being significantly higher than that of the Africans $(P<0.02)$.

TABLE IV.-Serum Cholesterol, Uric Acid, Platelet Stickiness, and Urinary Insulin Clearance in African, Indian, and White Subjects (Mean \pm S.D.)

\begin{tabular}{|c|c|c|c|c|}
\hline Subjects & $\begin{array}{c}\text { Serum } \\
\text { Cholesterol } \\
(\mathrm{mg} .100 \mathrm{ml} .)\end{array}$ & $\begin{array}{c}\text { Serum } \\
\text { Uric } \\
\text { Acid } \\
\text { (mg./100 ml.) }\end{array}$ & $\begin{array}{l}\text { Platelet } \\
\text { Stickiness } \\
\text { (\% of Initial } \\
\text { Count) }\end{array}$ & $\begin{array}{l}\text { Urinary } \\
\text { Insulin } \\
\text { Clearance } \\
\text { (ml./min.) }\end{array}$ \\
\hline $\begin{array}{l}\text { African } \\
\text { Indian } \\
\text { White }\end{array}$ & $\begin{array}{l}153 \pm 27 \\
186 \pm 26 \\
197 \pm 36\end{array}$ & $\begin{array}{l}4.5 \pm 0.8 \\
5.0 \pm 1.2 \\
5.8 \pm 0.8\end{array}$ & $\begin{array}{l}44 \pm 13 \\
43 \pm 7 \\
48 \pm 7\end{array}$ & $\begin{array}{l}0.22 \pm 0.06 \\
0.17 \pm 0.04 \\
0.34 \pm 0.09\end{array}$ \\
\hline
\end{tabular}

Urine Insulin Excretion.-The mean value for urine insulin in Whites was $1,022 \mu \mathrm{U}$./hour, while that of Africans was 440 and of Indians $444 \mu \mathrm{U}$./hour. This resulted in the mean insulin clearance of Whites $(0.34 \mathrm{ml} . / \mathrm{min}$.) being significantly higher than that of Indians $(0.17 \mathrm{ml} . / \mathrm{min}$.) and of Africans $(0.22 \mathrm{ml} . / \mathrm{min}$.), the $\mathrm{P}$ values being $<0.001$ and $<0.05$ respectively (Table IV).

Platelet Stickiness.-The platelet stickiness in fasting blood was similar in all three groups (Table IV).

\section{Discussion}

The interracial variations observed are all the more significant because the subjects studied were carefully matched and were comparable in the majority of their physical characteristics. Most striking were the differences between Africans and Whites. Despite similar mean blood glucose values at all times during the test, the Africans had lower serum insulin levels, a lower renal insulin clearance, a much greater rise of growth hormone during the late postabsorptive period, a more marked and prolonged suppression of free fatty acid release, lower serum cholesterol and uric acid levels, and a trend towards lower serum triglyceride values. Lower African levels for uric acid (Merskey et al., 1958), cholesterol (Walker and Arvidsson, 1954), and triglyceride (Antonis and Bersohn, 1960) have all been well documented. In a further study of 50 middle-aged non-diabetic outpatients we have confirmed that, in response to glucose loading, serum insulin levels of both normal weight and obese Africans are about half those of Indians or Whites of similar weight (Seftel et al., 1969).

The Indians in this study exhibited features of both other groups but tended to resemble White subjects more than Africans. Their serum insulin, growth hormone, cholesterol, and triglyceride levels were similar to those of Whites. Their mean blood glucose levels were higher than those of Whites and Africans, and suppression of free fatty acid release was more marked than in Africans at 30 minutes and greater than in Whites at 180 minutes. Urine insulin clearance was similar to that in Africans, while serum uric acid levels fell between African and White values. Walker (1966a) found serum cholesterol values in Johannesburg Indians to be similar to those of Whites, and it is generally agreed that hyperuricaemia and gout are common in South African Indians.

Viewed as a whole these findings suggest that the endocrine and peripheral tissues are reacting differently in the three races.
Compared with Whites, the Africans showed a smaller pancreatic and a greater pituitary response to a rise and fall in blood glucose respectively. Moreover, despite their lower insulin levels, glucose tolerance in Africans was similar to that in Whites, while their suppression of free fatty acid release from adipose tissue was more marked and prolonged. This suggests that the peripheral tissues in Africans are more sensitive to insulin than those of Whites. The Indians showed a different pattern. Their endocrine response, both pancreatic and pituitary, resembled that of Whites. However, the association of pronounced suppression of free fatty acid release with inferior glucose tolerance raises the interesting possibility that in Indians adipose tissue sensitive to insulin coexists with muscle relatively resistant to the hormone. This would be consistent with the most striking feature of Indian diabeticsnamely, the virtual absence of ketosis in both juvenile and maturity-onset cases (Campbell, 1963).

The reasons for these metabolic variations are unknown but must be related to genetic and environmental differences among the three races (Walker, 1966a, 1967). In brief, Johannesburg Whites and Indians are relatively affluent, sedentary, and enjoy a diet which is high in all nutrients. The majority of Indians are Moslems, among whom cousin marriages are very common. By contrast, the Africans have a much lower standard of living, they are physically active, and their diet is low in animal protein and fat and high in unrefined carbohydrates such as maize, bread, and sorghum.

It is unreasonable to expect that the delineation of insulingrowth hormone-substrate relationships in normal Whites, Africans, and Indians would afford an easy explanation for the interracial differences in disease pattern. Thus it could be argued that low serum insulin and high growth hormone levels in Africans should be associated with a higher rather than lower prevalence of diabetes, despite an increased sensitivity of the tissues to insulin. Nor do these findings explain why diabetes should be so common among Indians. On the other hand, low serum insulin levels in addition to the lower cholesterol and triglyceride values in Africans may help to explain their freedom from occlusive atherosclerosis. In Whites high serum insulin values have been reported in normoglycaemic patients with ischaemic heart disease (Nikkilä et al., 1965 ; Tzagournis et al., 1967) and peripheral vascular disease (Welborn et al., 1966a), and Mahler (1966) has presented evidence suggesting that hyperinsulinism may be atherogenic by promoting the accumulation of lipid within the arterial wall. It is also possible that high levels of growth hormone in Africans may prevent excessive lipogenesis in adipose tissue and arterial walls. The frequency of atherosclerotic disorders in Indians is not surprising in view of the many characteristics, biochemical and environmental, which they have in common with Whites. Further clarification of interracial differences may come from studies of hormonesubstrate relationships in diseased subjects, and these are now being undertaken.

We wish to thank Professor R. W. Charlton, of the Department of Pharmacology, Witwatersrand University, and Professor J. H. S. Gear, Director, South African Institute for Medical Research, for providing facilities. This study was supported by a grant for diabetic research from the South African Sugar Association to the Department of Medicine, University of the Witwatersrand.

\section{REFERENCES}

Antonis, A., and Bersohn, I. (1960). Lancet, 1, 998.

Campbell, G. D. (1963). S. Afr. med. F., 37, 1195. Lancet, 1, 806. Chlouverakis, C., Jarrett, R. J., and Keen, H. (1967). Lancet, 1, 806. (1961). F. clin. Path., 14, 450.

Folch, J., Lees, M., and Stanley, G. H. S. (1957). f. biol. Chem., 226, 497.

Hartog, M., Gaafar, M. A., Meisser, B., and Fraser, R. (1964). Brit. med. .., 2, 1229 .

Hoffman, W. S. (1937). f. biol. Chem., 120, 51. 
Mahlex, R. F. (1966). In Diabetes Mellitus, edited by L. J. P. Duncan,

Merskey, C., Gordon, H., and Lackner, H. (1958). S. Afr. med. F., 32, 855 .

Morgan, C. R., and Lazarow, A. (1963). Diabetes, 12, 115.

Morris, C. D. W., and Miller, K. (1966). S. Afr. f. med. Sci., 31, 45.

Nikkilä, E. A., Miettinen, T. A., Vesenne, M.-R., and Pelkonen, R. (1965). Lancet, 2, 508

Pearson, S., Stern, S., and McGavack, T. H. (1953). Anal. Chem., 25,

813.
Richardson, B. D., Walker, A. R. P., and Walker, B. F. (1965). Lancet, 2, 594 .

Ross, P. (1967). The Lipids of the Rat Femoral Marrow. M.Sc. thesis. University of the Witwatersrand, Johannesburg.

Rubenstein, A. H., Lowy, C., and Fraser, T. R. (1967a). Diabetologia, 3, 453.

Rubenstein, A. H., Lowy, C., Welborn, T. A., and Fraser, T. R. (1967b).

Metabolism, 16, 234.
Schnatz, J. D. (1964). F. Lipid Res., 5, 483.

Seftel, H. C., Keeley, K. J., and Walker, A. R. P. (1963a). S. Afr. med. f., 37, 1213.

Seftel, H. C., Keeley, K. J., and Walker, A. R. P. (1963b). Amer. f. Cardiol., 12, 148.

Seftel, H. C., Keeley, K. J., Walker, A. R. P., Theron, J. J., and DeLange, D. (1965). Geriatrics, 20, 194.
Seftel, H. C., Rubenstein, A. H., and Bersohn, I. (1969). In preparation. Society of Actuaries (1959). Build and Blood Pressure Study, vol. 1, p. 16. Quoted in Documenta Geigy Scientific Tables, 1962, 6th ed., p. 623 , edited by K. Diem. Basle.

Trout, D. L., Estes, E. H., and Friedberg, S. J. (1960). Э. Lipid Res., 1, 199.

Tzagournis, M., Seidensticker, J. F., and Hamwi, G. J. (1967). Ann. intern. Med., 67, 42.

Van Handel, E., and Zilversmit, D. B. (1957). F. Lab. clin. Med., 50, 152.

Walker, A. R. P. (1963a). Amer. Heart f., 66, 293.

Walker, A. R. P. (1963b). S. Afr. med. F., 37, 1155.

Walker, A. R. P. (1966a). S. Afr. med. 7., 40, 814

Walker, A. R. P. (1966b). S. Afr. med. Ұ., 40, 834

Walker, A R P (1967). Amer. F. clin. Nutr., 20, 1025

Walker, A R P. and Arvidsson, U. B. (1954) 7. clin. Invest., 33, 1358.

Walker, A. R. P., Richardson, B. D., and Mistry, S. D. (1964). Brit. med. F., 2, 1394 .

Welbarn, T. A., and Fraser, T. R. (1966). Diabetologia, 1, 211

Welborn, T. A., Breckenridge, A., Rubinstein, A. H., Dollery, C. T., and Fraser, T. R. (1966a). Lancet, 1, 1336.

Welborn, T. A., Rubenstein, A. H., Haslam, R., and Fraser, R. (1966b). Lancet, 1, 280.

Wootton, I. D. P. (1964). Micro-analysis in Medical Biochemistry, 4th ed., p. 213. Churchill, London.

\title{
Effect of Frusemide on Calcium Excretion
}

\author{
J. A. TAMBYAH, $* \dagger$ M.B., B.S., M.R.A.C.P. ; M. K. L. LIM,*¥ L.R.C.P., M.R.C.S.
}

Brit. med. F., 1969, 1, 751-752

\begin{abstract}
Summary : After giving oral frusemide (Lasix) to 14 normal volunteers significant hypercalciuria occurred in all of them. This could not be accounted for by any change in glomerular filtration rate, but was possibly due to decreased tubular reabsorption.
\end{abstract}

\section{Introduction}

Previous workers have described an effect of thiazide diuretics on calcium excretion and have suggested the possibility of the use of the thiazides in the therapy of idiopathic hypercalciuria. Duarte (1967) has shown an increased clearance of ultrafilterable calcium in dogs infused with frusemide (Lasix) -an effect contrary to that found with the thiazides. Hänze and Seyberth (1967) also confirmed this in normal subjects with intravenously administered frusemide, ethacrynic acid, and oral triamterene. In view of these conflicting reports on such an important issue we have undertaken the study of the effects of frusemide on the urinary excretion of calcium in normal subjects following oral administration of the drug.

\section{Materials and Methods}

Fourteen members of the staff volunteered for the trial. Urine was collected over an eight-hour period, from 9 a.m. to 5 p.m., on two consecutive working days. Blood samples were taken in the middle of the collection period with the usual precautions required for calcium estimation. Frusemide $80 \mathrm{mg}$. was given at 9 a.m. on the second collection day. There was no restriction on diet or fluid intake in the two periods of study.

* Fellow in Biochemistry, Department of Biochemistry, Royal Mebbourne Hospital, Victoria.

t Present address: Medical Unit, Thomson Road General Hospital, Singapore.

¥ Present address: Department of Pathology, University of Malaya, Kuala Lumpur.
Serum and urinary creatinine were estimated by using the Jaffe reaction as modified for the autoanalyser, and osmolalities were measured on the advanced osmometer by use of freezingpoint depression. Serum and urine calciums were estimated by an automated fluorometric method described by Martin and Baird (1965); urine calciums were also estimated by the atomic absorption spectrophotometric method of Willis (1960).

\section{Results}

The Chart gives the results of urinary calcium determinations carried out on the 28 specimens by the two methods mentioned. The correlation coefficient was 0.9916.

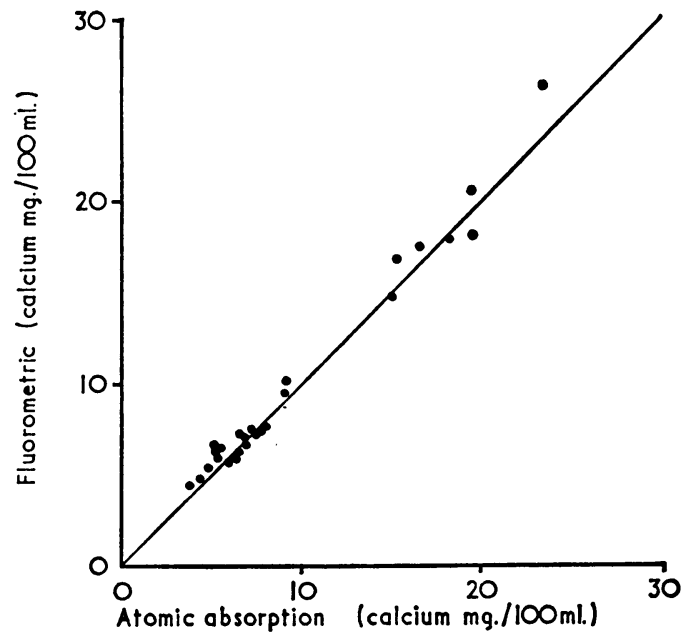

Comparison of urine calcium values of fluorometric and atomic absorption methods. 